\section{Animals' rights and wrongs}

SIR - The case for animal rights is really much simpler than your anonymous article (Nature 24 March, p.287) would suggest. Whilst animals differ from us in many ways, such as intelligence, strength, language and appearance, these differences are entirely arbitrary and can occur within our own species. Animals are like us in one crucial respect - they too can experience pain, fear and stress, and on that basis the National Anti-Vivisection Society believes they should receive the same respect and consideration we would expect for each other. The suffering which is so often inseparable from animal experimentation, and the intensive forms of animal husbandry, hardly approach this ideal.

It is only the enormous implications of such an ethical revolution that complicate the issue. In the same way, logical arguments for the abolition of slavery were clouded by implications of economic collapse.

In the case of animal experiments, numerous powerful influences work to keep the status quo. The introduction of potentially highly profitable products is legally dependent on animal tests whilst scientists will be averse to losing one of their traditional "research tools". Nor should we forget the laboratory animal breeders and associated industries.

With such powerful vested interests there has been understandable, though lamentable, lack of government sympathy. But recent moves to link votes with animal protection promise to make this an important political issue and it may well be that governments will be finally persuaded to take steps towards reform. To begin with this could mean eliminating the LD50 test, restricting funds for the use of animals in psychological and behavioural research, and real government support for the development of alternative methodologies. In the case of toxicity testing, at least, the need for humane and more reliable tests has long been apparent.

Yet how much better it would be for government and scientists to take the initiative now and respond positively to growing public concern, instead of acting defensively as your article rather negatively suggests. The question of animal rights can no longer be ignored.

Roblet SHARPE:

National Anti-Vivisection Society,

London $W 1$, UK

SIR - Your News and Views comment, "Do laboratory animals have rights?", (Nature 24 March, p.287) fails to point out that Professor Peter Singer's notions of animal rights, though popular, have dubious foundations.

(1) Peter Singer ignores the basic distinctiveness of the human experience of pain that underlies morality. While nonhumans experience pain in isolation from any beliefs, it is a species-specific characteristic of human suffering that it is modified by beliefs concerning its aetiology. A simple example of this is the exclusively human phenomenon of placebos. A more complex example is the different affective reactions people have to similar injuries when they believe they are accidents compared with when they believe they are the products of intention. People also suffer differently a similar physical injury according to whether they have consented for example to medical treatment or have it done against their will. There is no comparable sentience in nonhumans. The involvement of beliefs is central to human experience and our sentient nature. It not only underlies our capacity to conceptualize moral frameworks but the human need for them.

(2) His attack on "speciesism" using analogies that animal experience has with that of retarded and infant humans ignores the importance of generalizing human rights to all classes of human experience. If certain groups of humans were exempted there could be the risk that by accident or design - witness present-day psychiatric practice in the Soviet Union - fully sentient humans would be denied their rights by being misclassified.

(3) For most of this century antivivisectionists have concluded, since we cannot predict the beneficial consequences of pure research using vivisection, that no moral obligation to human welfare is effected by restricting it in the interests of animal welfare. However, though on any particular occasion of its being asserted this is no doubt true, retrospectively all such claims until now have been shown to be false by the sequential development of medical science. I cannot invalidate Peter Singer's claims that in restricting vivisection he is not restricting future human welfare, but it is clear that all previous assumptions to this effect have been shown to be erroneous and present-day claims might be equally so. It is reasonable to be believe that restricting research in the name of animal rights is to act contrary to our moral obligations to future generations not knowingly to restrict the opportunities they might have to alleviate or prevent human suffering. To have acted on animal rights in the past would have denied many patients today the care that medical progress has produced. Can it be right to deny the future improvement in treatment efficacy consequent to implementing the unproven concept of animal rights?

\section{London NW3, UK}

JWHN R. SKCYYIILS

SIR - The cacophonous neologism "speciesism" is used (Nature 24 March, p.287) in a discussion of animal experimentation, quoting Professor Peter Singer. Singer's dicta extend beyond this; he has been quoted as saying ${ }^{1}$ : "What are we to do about genuine conflicts of interest like rats biting slum children? ... the essential point is just that we do see this as a conflict of interests, that we recognize that rats have interests too."

A candidate for the Sierra Club Board of Directors has pushed it a little further in his election statement by saying "All life forms from blue whales to bacteria have an equal right to exist". This raises the question of the abrogation of the rights of intestinal coliforms by the end result of peristalsis. Also, it is doubtful whether pathogenic microorganisms perceive the rights of their hosts. It brings us back to the darwinian notion of the struggle for existence, in which our own species has been perhaps over-successful, but not sufficiently successful as to stop competing with other biota. Obviously the inflicting of needless pain is to be avoided.

\section{Department of Biophysics} and Medical Physics, University of California, Berkeley, USA

1. Parity Foundation Newsmagazine Vol, 1,7 (1981).

\section{Toxin gene cloning}

SIR - In considering the applicability of cloned toxin genes to biological warfare, James Larrick's letter (and indeed, the title your editors attached to it, "Beware cloned toxins") suggests that cloned toxins are more dangerous than these toxins produced in their natural hosts (Nature 24 February, p.651). This is highly improbable. In fact, it is likely that these cloned toxins will be less dangerous (in Escherichia coli $\mathrm{K}-12$, at least) because of the differences in cellular compartmentalization and post-translational processing which must accompany the secretion of these toxic proteins from their natural hosts.

The example cited by Mr Larrick, diphtheria toxin, illustrates this point well. Diphtheria toxin produced by certain (widely available) strains of Corynebacterium diphtheriae may produce and secrete up to $500 \times \mathrm{g}$ per millilitre of diphtheria toxin (this is equivalent to about 70,000 human $\mathrm{LD}_{50} \mathrm{~s}$ per litre). One hardly needs a recombinant $E$. coli strain to manufacture this toxin. In addition, the highly toxinogenic strains of C. diphtheriae mentioned above are essentially avirulent due to their inability to colonize the throat, pointing to the multifactorial requirements of virulence.

There is a great need for public awareness about the potential dangers and abuses of chemical and biological warfare. The particular letter you chose to print, however, did little to advance this objective.

Harvard Medical School,

KeN COLEMAN

Boston, Massachusetts, USA 